\title{
Meltwater-induced relocation of chemical species in Alpine firn
}

\author{
By ANJA EICHLER ${ }^{1,2}$, MARGIT SCHWIKOWSKI ${ }^{1 *}$ and HEINZ W. GÄGGELER ${ }^{1,2},{ }^{1}$ Paul \\ Scherrer Institute, CH-5232 Villigen PSI, Switzerland; ${ }^{2}$ Department of Chemistry and Biochemistry, \\ University of Bern, Freiestrasse 3, CH-3012 Bern, Switzerland
}

(Manuscript received 31 January 2000; in final form 10 November 2000)

\begin{abstract}
In order to interpret glaciochemical records with respect to the history of air pollution, an understanding of post-depositional processes taking place in firn and ice is crucial. In a 13-m firn section of an Alpine ice core, we observed a drastic disturbance of the concentration records of certain ionic species which we attribute to the inflow of meltwater. This observation opened up the possibility to investigate the effects of leaching processes on the chemical composition of a natural firn layer. Species were leached with different efficiencies: Whereas the normal seasonal pattern of the concentrations of $\mathrm{NH}_{4}^{+}, \mathrm{F}^{-}, \mathrm{Cl}^{-}$, and $\mathrm{NO}_{3}^{-}$and of the $\delta^{18} \mathrm{O}$ values was preserved, concentrations of $\mathrm{K}^{+}, \mathrm{Na}^{+}, \mathrm{Mg}^{2+}, \mathrm{Ca}^{2+}$, and $\mathrm{SO}_{4}^{2-}$ were significantly decreased. From the patterns of the concentration ratios the elution sequence $\mathrm{SO}_{4}^{2-}>\mathrm{Ca}^{2+} \sim \mathrm{Mg}^{2+}>$ $\mathrm{K}^{+} \sim \mathrm{Na}^{+} \gg \mathrm{NO}_{3}^{-}>\mathrm{NH}_{4}^{+} \sim \mathrm{F}^{-}>\mathrm{Cl}^{-}$was established, which could be explained by ion rearrangement during snow metamorphism. An incorporation of the species $\mathrm{Cl}^{-}, \mathrm{F}^{-}, \mathrm{NH}_{4}^{+}$, and $\mathrm{NO}_{3}^{-}$into the ice lattice during grain growth caused their least efficient scavenging by percolating meltwater. In contrast, the predominate exclusion of the ions $\mathrm{SO}_{4}^{2-}, \mathrm{Ca}^{2+}, \mathrm{Mg}^{2+}$, $\mathrm{K}^{+}$, and $\mathrm{Na}^{+}$from the ice lattice due to their low solubility in ice and the subsequent segregation at grain surfaces led to the fast removal of these species from the firn layer.
\end{abstract}

\section{Introduction}

Ice core records of chemical trace compounds have been proven to be invaluable sources of information about past environmental conditions. However, they are not only determined by the atmospheric concentration of the species and the deposition processes, but additionally by postdepositional processes taking place in firn or ice. One example is diffusion processes in firn and ice, which lead to smoothing of chemical signals with depth of the ice, such as those of $\mathrm{H}_{2} \mathrm{O}_{2}$ (Sigg and Neftel, 1991) and the isotopic ratio ${ }^{18} \mathrm{O} /{ }^{16} \mathrm{O}$ (Johnsen, 1977). Wagnon et al. (1999) showed that concentration profiles of the species fluoride,

\footnotetext{
* Corresponding author.

e-mail: margit.schwikowski@psi.ch
}

chloride, nitrate, and methanesulphonate, partly deposited as gases, exhibit a rapid decrease in the upper firn layers at Vostok, Antarctica. This indicates that a fraction of these compounds is expelled back into the atmosphere after deposition. However, the phenomenon was only observed at such a low accumulation site (generally less than $10 \mathrm{~cm}$ water equivalent $\mathrm{y}^{-1}$ ). An escape of $\mathrm{HF}$ from acidic firn layers to basic (calcium-rich) layers was detected in an ice core from Summit, Greenland (de Angelis and Legrand, 1994). Investigations of an ice core from Siple Dome (Antarctica) showed a migration of methanesulphonic acid and nitrate from acidic summer to less acidic winter layers (Kreutz et al., 1998). Another example is chemical reactions of impurities affecting ice core records. The reaction of acids with carbonates may lead to a post-depositional 
production of $\mathrm{CO}_{2}$ (Delmas, 1993). The catalytic decomposition of $\mathrm{H}_{2} \mathrm{O}_{2}$ in dust-containing, alkaline ice is a possible mechanism for $\mathrm{H}_{2} \mathrm{O}_{2}$ loss (Wolff, 1996).

Furthermore, the original composition of glacier firn or ice can be changed by rain or meltwater. This process occurs mainly in temperate glaciers, if the temperatures are near the freezing point. The influence of meltwater on the composition of natural snowpacks has been studied in several field and laboratory works (Johannessen and Henriksen, 1978; Brimblecombe et al., 1985; Brimblecombe et al., 1987; Bales et al., 1989; Hewitt et al., 1991). The initial aim for most of these works was the investigation of the so called 'acid flush' from snow packs due to melting in spring causing severe ecological damage on lakes and rivers as well as physiological stress to fish and other aquatic organisms. It has been shown that between 50 and $80 \%$ of the snowpack solute load may be lost within the initial $20-30 \%$ of the meltwater and that different solutes are not leached with the same efficiency (see e.g., Johannessen and Henriksen, 1978; Brimblecombe et al., 1987; Bales et al., 1989).

In order to relate ice core records to past atmospheric composition, either the absence of post-depositional processes or their quantification is necessary.

We report here on chemical and isotopic measurements carried out on the top $39 \mathrm{~m}$ water equivalent (w.eq.) of an Alpine ice core from the upper Grenzgletscher. Concentration records of certain ionic species were drastically disturbed which we assume was due to percolation of meltwater. Leaching processes aggravate the interpretation of a $13 \mathrm{~m}$ w.eq. part of the ice core. However, this part of the core offers the unique possibility to study the post-depositional effects of meltwater induced leaching of trace compounds from firn layers under field conditions. Such process studies help to assess the potential of temperate glaciers to preserve valuable palaeoenvironmental information. Even the limited use of temperate glaciers as archives would significantly extend the areas of the world accessible for palaeo-atmospheric and climate research.

\section{Methods}

The study site $\left(45^{\circ} 55^{\prime} \mathrm{N}, 7^{\circ} 52^{\prime} \mathrm{E}\right)$ is situated at the upper part of the Grenzgletscher, located at the Monte Rosa massif in the Swiss Southern Alpine chain (Wallis Alps) near the Swiss-Italian border. The upper Grenzgletscher is embedded between the Monte Rosa summit Dufourspitze (4634 $\mathrm{m}$ a.s.l.) and the Liskamm (4527 $\mathrm{m}$ a.s.l.) (Fig. 1). A deep drilling of $125 \mathrm{~m}$ was performed in October 1994 at an elevation of $4200 \mathrm{~m}$ a.s.l (Gäggeler et al., 1997). The glacier thickness at the drilling site is about $190 \mathrm{~m}$ (Eichler et al. 2000). Measurements of the borehole temperatures (Suter, 1995) indicate that the Grenzgletscher consists of cold firn and ice down to an altitude of at least $4000 \mathrm{~m}$ a.s.1.

During the campaign ice core sections (0.5-0.8 m long) with a diameter of $7.8 \mathrm{~cm}$ were electromechanically drilled, packed, sealed in polyethylene tubes and afterwards kept frozen in a cold room at $-25^{\circ} \mathrm{C}$. The ice core sections were cut into $5 \mathrm{~cm}$ pieces and the outer $1.5 \mathrm{~cm}$ removed with a modified band-saw. The decontaminated samples were placed in plastic tubes and melted under inert gas $\left(\mathrm{N}_{2}\right)$ atmosphere just before their analysis. The determination of the main soluble inorganic cations $\left(\mathrm{Na}^{+}, \mathrm{NH}_{4}^{+}, \mathrm{K}^{+}, \mathrm{Mg}^{2+}, \mathrm{Ca}^{2+}\right)$ and anions $\left(\mathrm{F}^{-}, \mathrm{Cl}^{-}, \mathrm{NO}_{3}^{-}, \mathrm{SO}_{4}^{2-}\right)$ was performed by ion chromatography with conductivity detection. The analysis of the isotopic ratio $\delta^{18} \mathrm{O}$ was carried out by using an isotope mass spectrometer. For details regarding the sample preparation and the chemical analyses, see Eichler et al. (2000).

Ice core dating was performed by using the radioactive decay of the isotope ${ }^{210} \mathrm{~Pb}$ and by annual layer counting utilizing the strong seasonal pattern of the $\mathrm{NH}_{4}^{+}$concentrations and the $\delta^{18} \mathrm{O}$ values. Additionally, reference horizons were used for dating. The strong Saharan dust falls in 1947, 1977 and 1990, the maxima of the atmospheric nuclear weapon tests in 1962 and 1958 and the reactor accident in Chernobyl in 1986 could be detected in the ice core. We determined the time period covered by the $125 \mathrm{~m}$ ( $104 \mathrm{~m}$ w.eq.) long ice core to be 1937-1994 with a mean annual accumulation rate of $2.7 \mathrm{~m}$ w.eq. (Eichler et al., 2000).

\section{Results and discussion}

\subsection{The behaviour of the major ions and $\delta^{18} \mathrm{O}$ in firn during the inflow of meltwater}

$\mathrm{NH}_{4}^{+}$and $\mathrm{SO}_{4}^{2-}$ concentrations from the upper $39 \mathrm{~m}$ w.eq. of the Grenzgletscher ice core are 


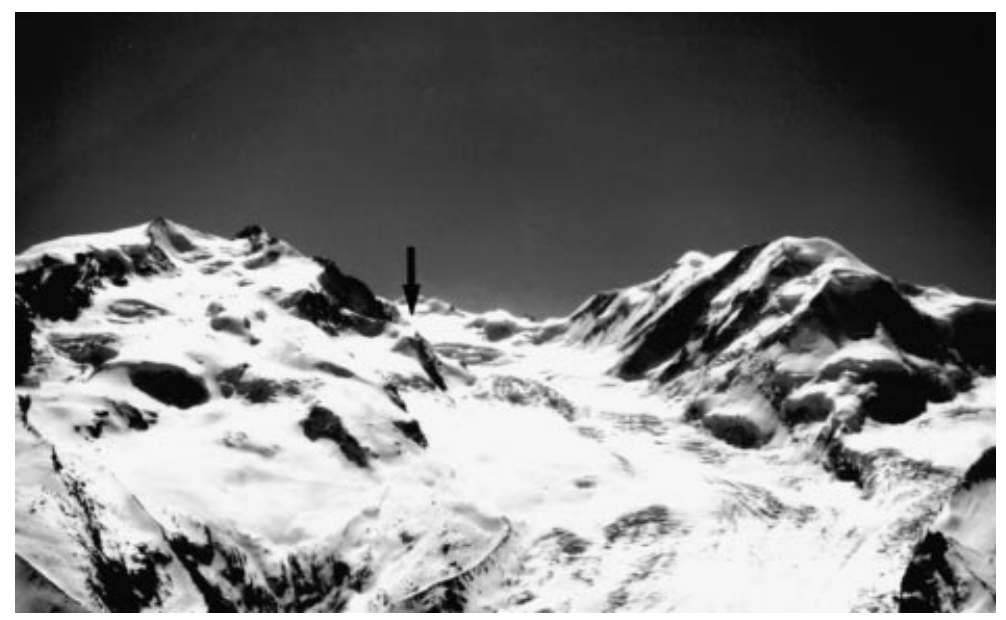

Fig. 1. View of the upper Grenzgletscher in the Monte Rosa massif from the west with the drilling position in 1994 at $4200 \mathrm{~m}$ a.s.l. (arrow), located between the Monte Rosa summit Dufourspitze (4634 m a.s.l., left) and the Liskamm (4527 m a.s.l., right). Photo by S. Sutter, 1994.

presented in Fig. 2. This part of the ice core covers the time period between 1980 and 1994. Because of poor ice quality, the section between 25 and $25.5 \mathrm{~m}$ w.eq. could not be analysed. As described elsewhere (Maupetit et al., 1995; Schwikowski et al., 1999), the concentrations of $\mathrm{NH}_{4}^{+}$and $\mathrm{SO}_{4}^{2-}$ show a sharply pronounced seasonal pattern in high altitude Alpine glaciers, mainly due to the seasonally dependent atmospheric transport processes to the high-alpine sites (Lugauer et al., 1998). Summer to winter concentration ratios of 4-14 and 2-6 were determined for $\mathrm{NH}_{4}^{+}$and $\mathrm{SO}_{4}^{2-}$, respectively. Strong seasonal cycles are also observable in the $\mathrm{NH}_{4}^{+}$and $\mathrm{SO}_{4}^{2-}$ concentration

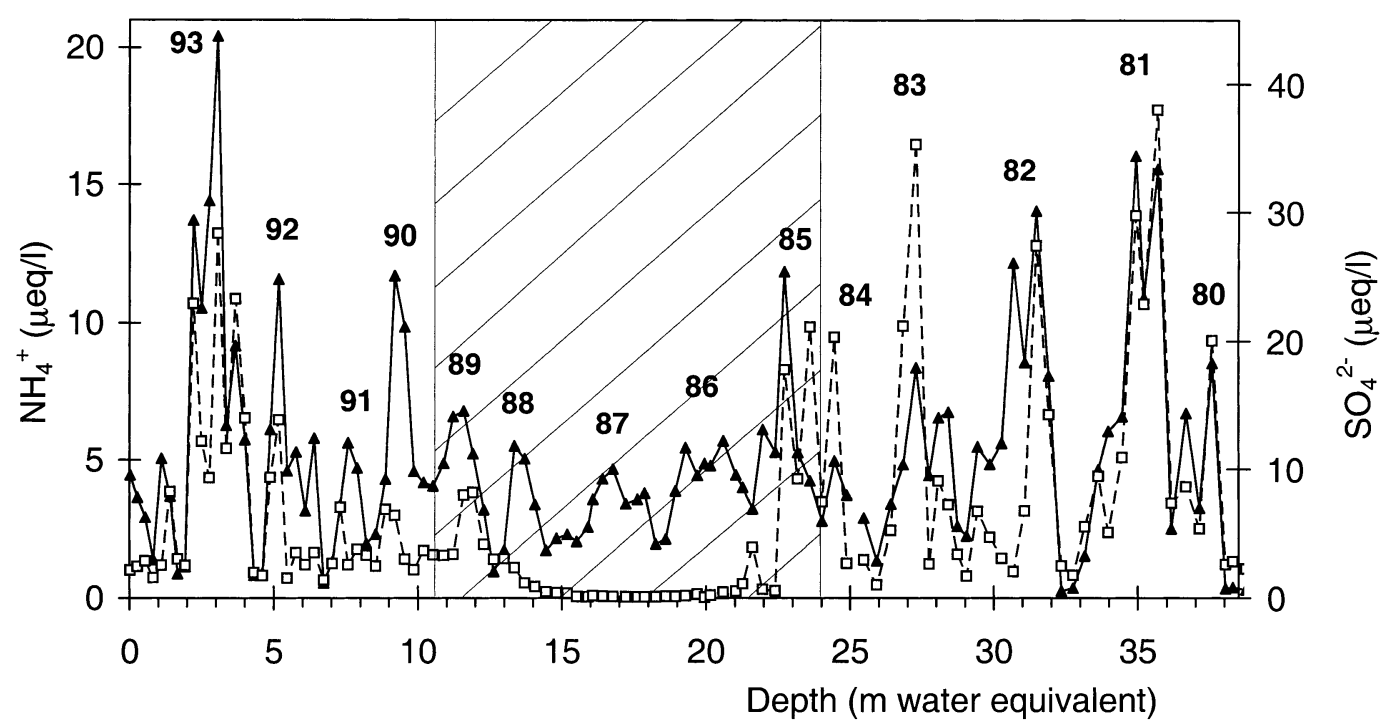

Fig. 2. Record of the $\mathrm{NH}_{4}^{+}$(solid line) and $\mathrm{SO}_{4}^{2-}$ concentrations (dashed line) along the upper $52 \mathrm{~m} \mathrm{(39} \mathrm{m} \mathrm{water}$ equivalent) of the ice core, covering the time period 1980-1994 (individual years indicated). Given are average concentration values of $50 \mathrm{~cm}$ ice core segments. The range presumably influenced by the meltwater is marked. 
records of the Grenzgletscher ice core down to $12.5 \mathrm{~m}$ w.eq. Below this depth the $\mathrm{SO}_{4}^{2-}$ concentrations decreased rapidly down to values near the detection limit of the analytical method $(0.01 \mu \mathrm{eq} / 1)$. In contrast, the seasonal pattern of the $\mathrm{NH}_{4}^{+}$concentrations seems to have been preserved. Only at a depth of approximately $21 \mathrm{~m}$ w.eq. does the $\mathrm{SO}_{4}^{2-}$ concentration start to increase again. Deeper in the core (below depths of nearly $24 \mathrm{~m}$ w.eq.) both, $\mathrm{NH}_{4}^{+}$and $\mathrm{SO}_{4}^{2-}$ concentrations seem to be undisturbed.

Concentrations of the anions $\mathrm{F}^{-}, \mathrm{Cl}^{-}$, and $\mathrm{NO}_{3}^{-}$kept their initial seasonal pattern comparable to $\mathrm{NH}_{4}^{+}$in the range between 11 and $24 \mathrm{~m}$ w.eq. of the ice core, whereas the cations $\mathrm{K}^{+}$, $\mathrm{Na}^{+}, \mathrm{Mg}^{2+}$, and $\mathrm{Ca}^{2+}$ behaved similar to $\mathrm{SO}_{4}^{2-}$ (Fig. 3). The mean concentrations of all major ions analysed and the mean $\mathrm{pH}$ are shown in Table 1 for the upper $39 \mathrm{~m}$ w.eq. (except the depth 11-24 m w.eq.).

In addition to the main ionic species the isotopic ratio ${ }^{18} \mathrm{O} /{ }^{16} \mathrm{O}$ was determined. The $\delta^{18} \mathrm{O}$ value contains information about the isotopic composition of the water molecule during precipitation formation itself, which is dependent on the condensation temperature (Dansgaard, 1964). We compared monthly mean $\delta^{18} \mathrm{O}$ values with temperature data from the $50 \mathrm{~km}$ distant weather station at Col du Gd. St. Bernard (2469 m a.s.1.) (Fig. 4). A reasonable agreement was found in the time period 1980-1994 $(r=0.7)$. The derived $\delta^{18} \mathrm{O}$ temperature relation of $1 \%$ o per ${ }^{\circ} \mathrm{C}$ is in good agreement with that from other alpine sites (Schotterer et al., 1997). This indicates that the $\delta^{18} \mathrm{O}$ record was preserved.

The reason for the nearly complete removal of some species in firn is most probably the elution by meltwater. The inflow of meltwater at the drilling site was predicted by Suter (1995) on the basis of borehole temperature measurements. Fig. 5 (right panel) shows the measured temperature profile along the upper $40 \mathrm{~m}$ w.eq. A temperature anomaly can be observed in depths between approximately 10 and $25 \mathrm{~m}$ w.eq. with a temperature maximum of $-1{ }^{\circ} \mathrm{C}$ in about $18 \mathrm{~m}$ w.eq. depth. One reason for these high temperatures could for instance be a melting of this $\sim 15 \mathrm{~m}$ w.eq. thick layer down from the surface in 1989 or 1990 caused by extremely warm conditions. However, due to the heat exchange with the surrounding firn and ice, the high temperatures of $-1^{\circ} \mathrm{C}$ could not have been preserved until 1994 (date of the drilling) (Suter, 1995). Another possibility is a meltwater percolation from the surface down to depths of about $24 \mathrm{~m}$ w.eq. in 1994. In this case, records of trace species would not have been preserved in the upper $11 \mathrm{~m}$ w.eq. (Fig. 3). A third, more likely explanation, is a horizontal inflow of meltwater. The meltwater originated most probably from a crevasse system located above the drilling site at Grenzgletscher. Meltwater formation at the walls of these crevasses has indeed been observed (Suter, 1995). From our concentration records we assume an inflow of meltwater at a depth of approximately 11-12 m w.eq. The meltwater then percolated through the underlying firn layers mainly along the grain surfaces. Evidence that the main part of the firn remained preserved and was not melted at all is the optical appearance of the core, with firn layers still present between ice lenses. Another hint is gained from the measured $\delta^{18} \mathrm{O}$ record, which is obviously not affected by the meltwater percolation (Fig. 4) (see above). Nevertheless, the percolating meltwater mobilised a part of the chemical species in the firn layer. As described in different studies (Goto-Azuma et al., 1994) the enriched solution can stop in the firn if the temperatures are low enough for refreezing or at the impermeable firn/ice boundary. Such processes may lead to extremely high concentrations of the species released from firn in the refrozen layers, which may even increase with the number of melt-freeze cycles (Davis, 1991). Because there is no evidence for an enrichment of any species in our data (Fig. 3), we assume draining of the meltwater at a depth of 20-24 m w.eq. without refreezing. From the density profile (Fig. 5, left) we can deduce that the firn-ice transition was approximately at a depth of $18 \mathrm{~m}$ w.eq. $\left(\rho \sim 0.8 \mathrm{~g} / \mathrm{cm}^{3}\right.$, Schwander, 1996). Taking into account the mean annual accumulation rate of $2.7 \mathrm{~m}$ w.eq., we assume that the percolating meltwater drained along the horizontal firn-ice border in 1992 (Fig. 5, firn-ice transition $\sim 24 \mathrm{~m}$ w.eq.). A scheme of the assumed meltwater flow at the drilling site is shown in Fig. 6.

\subsection{Determination of the elution sequence}

As described in various field and laboratory studies (Brimblecombe et al., 1987; Tranter et al., 

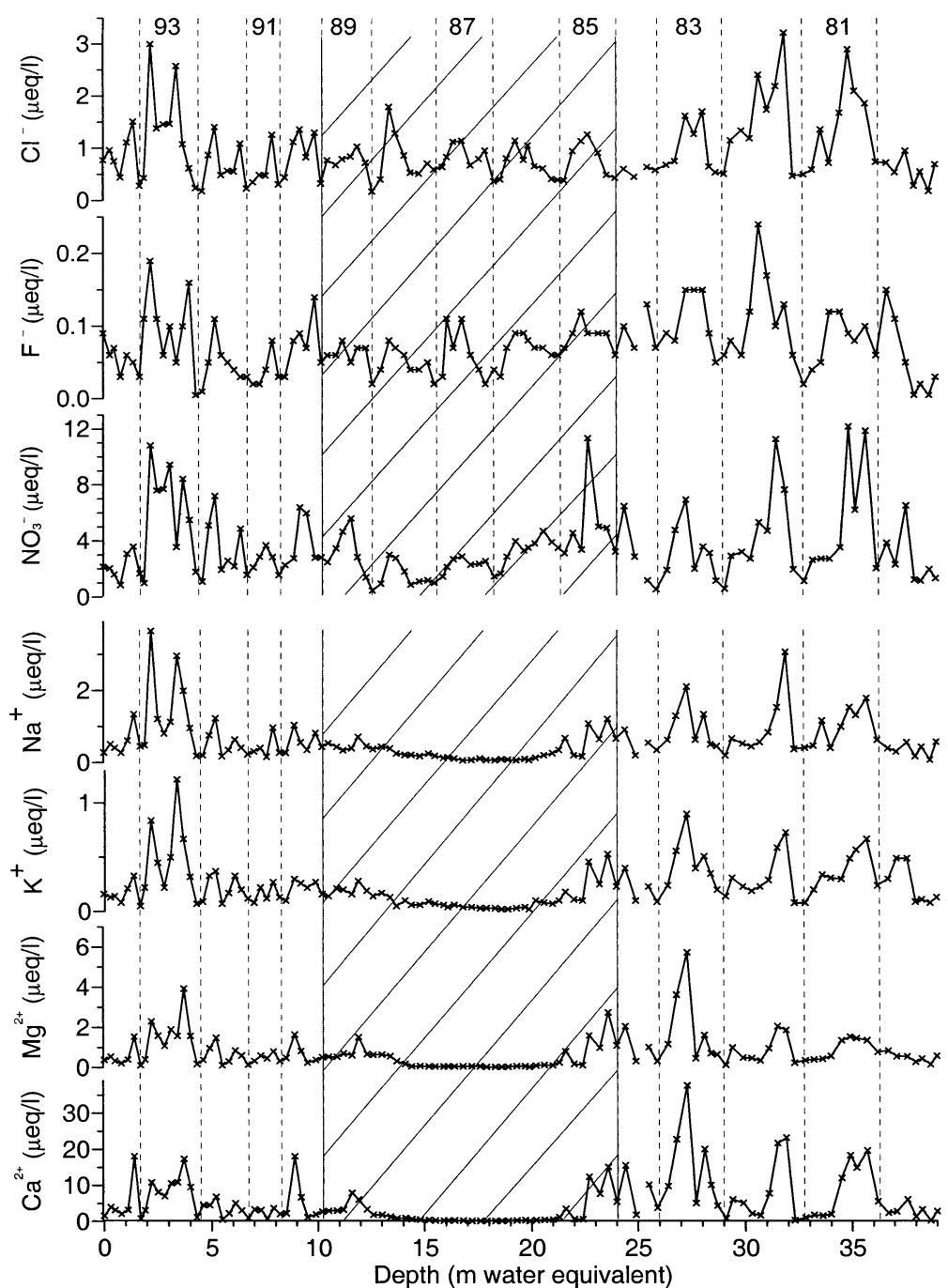

Fig. 3. Same as Fig. 2, but for concentrations of $\mathrm{NO}_{3}^{-}, \mathrm{F}^{-}$, and $\mathrm{Cl}^{-}$(top) and $\mathrm{Ca}^{2+}, \mathrm{Mg}^{2+}, \mathrm{K}^{+}$, and $\mathrm{Na}^{+}$(bottom). Dashed lines represent annual layers between 1980 and 1994 .

Table 1. Mean concentrations of the major ions and the mean $\mathrm{pH}$ of the ice core in the upper $39 \mathrm{~m}$ w.eq. (except 11-24 w.eq. depth)

\begin{tabular}{lclcll}
\hline & $c(\mu \mathrm{eq} / 1)$ & \multicolumn{5}{c}{$c(\mu \mathrm{eq} / 1)$} \\
\hline $\mathrm{Ca}^{2+}$ & 3.0 & $\mathrm{Cl}^{-}$ & 0.57 & $\mathrm{pH}$ & 5.49 \\
$\mathrm{~K}^{+}$ & 0.19 & $\mathrm{~F}^{-}$ & 0.06 & & \\
$\mathrm{Mg}^{2+}$ & 0.49 & $\mathrm{NO}_{3}^{-}$ & 2.5 & & \\
$\mathrm{Na}^{+}$ & 0.42 & $\mathrm{SO}_{4}^{2-}$ & 3.7 & & \\
$\mathrm{NH}_{4}^{+}$ & 3.4 & & & & \\
\hline
\end{tabular}

1992), ions are leached from snow and firn with different efficiencies. In most cases the elution sequence was determined by comparing the concentrations of the different ions in the meltwater leaving an investigated snow pack. Since it is in our case not possible to reconstruct the composition of the draining meltwater, we determined the elution sequence from the concentration records of the species remaining in the firn. Due to the strongly decreased concentrations of $\mathrm{SO}_{4}^{2-}, \mathrm{K}^{+}$, $\mathrm{Na}^{+}, \mathrm{Mg}^{2+}$, and $\mathrm{Ca}^{2+}$ we can conclude that these ions were leached more efficiently than $\mathrm{NH}_{4}^{+}, \mathrm{F}^{-}$, 


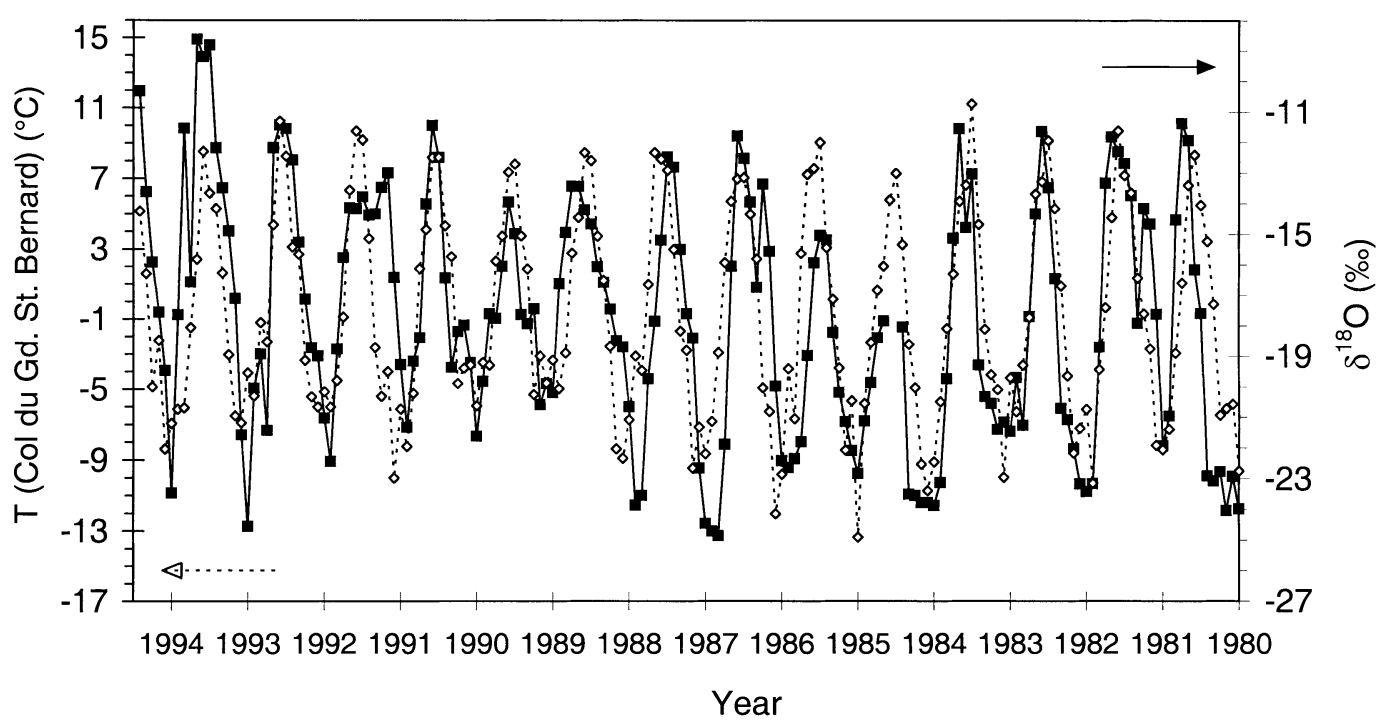

Fig. 4. Monthly mean $\delta^{18} \mathrm{O}$ values of the ice core (solid line) together with monthly mean temperatures at the weather station Col du Gd. St. Bernard (dashed line) between 1980 and 1994.

$\mathrm{Cl}^{-}$, and $\mathrm{NO}_{3}^{-}$. In order to study differences for ions of one group, we investigated their concentration ratios. As an example, the ratio $\mathrm{NH}_{4}^{+} / \mathrm{NO}_{3}^{-}$ is shown in Fig. 7A. For undisturbed conditions, we would expect a seasonal variation of this ratio, due to the different emission characteristics of the precursor species $\left(\mathrm{NH}_{3}, \mathrm{NO}_{x}\right)$ of the deposited ions and assuming a similar transport of both species from their sources to the high alpine sites. While $\mathrm{NH}_{3}$ is emitted predominantly during summer from agriculture, $\mathrm{NO}_{x}$ emissions originating mainly from traffic are nearly uniformly distributed throughout the year (BUWAL, 1999). Indeed, the well pronounced seasonal pattern of the $\mathrm{NH}_{4}^{+} / \mathrm{NO}_{3}^{-}$ratio disappeared only in the depth range influenced by meltwater. Within this range, we observed an almost linear decrease of the ratio due to a different elution strength for both ions. Fig. 7B shows the absolute $\mathrm{NH}_{4}^{+}$and $\mathrm{NO}_{3}^{-}$concentrations between 12 and $24 \mathrm{~m}$ w.eq. A stronger increase of $\mathrm{NO}_{3}^{-}$in comparison to $\mathrm{NH}_{4}^{+}$concentration, which led to the decrease in the $\mathrm{NH}_{4}^{+} / \mathrm{NO}_{3}^{-}$ratio with depth, indicates a preferential elution of $\mathrm{NO}_{3}^{-}$with respect to $\mathrm{NH}_{4}^{+}$. From the concentration ratios between the investigated ions we determined the following elution sequence:

$$
\begin{gathered}
\mathrm{SO}_{4}^{2-}>\mathrm{Ca}^{2+} \sim \mathrm{Mg}^{2+}>\mathrm{K}^{+} \sim \mathrm{Na}^{+} \\
\gg \mathrm{NO}_{3}^{-}>\mathrm{NH}_{4}^{+} \sim \mathrm{F}^{-}>\mathrm{Cl}^{-} .
\end{gathered}
$$

$\mathrm{SO}_{4}^{2-}$ is most preferentially leached by the meltwater, whereas $\mathrm{Cl}^{-}$seems to keep its initial concentration. The fact that $\mathrm{Cl}^{-}$is little affected by the meltwater is supported by the fact that the $\mathrm{Cl}^{-}$concentrations do not show an increase with depth in the considered range as it was observed for $\mathrm{NO}_{3}^{-}$and $\mathrm{NH}_{4}^{+}$(Fig. 3).

The elution order for the anions $\mathrm{SO}_{4}^{2-}>$ $\mathrm{NO}_{3}^{-}>\mathrm{Cl}^{-}$is in good agreement with those derived from laboratory and field experiments (Tranter et al., 1992; Brimblecombe et al., 1987; Brimblecombe et al., 1985). An elution sequence including anions and cations of $\mathrm{SO}_{4}^{2-}>\mathrm{Ca}^{2+}$ $\sim \mathrm{Mg}^{2+}>\mathrm{K}^{+}>\mathrm{Na}^{+}>\mathrm{NO}_{3}^{-}>\mathrm{Cl}^{-}$can be deduced from laboratory experiments carried out by Hewitt et al. (1989) by rinsing deionized water through a glass column packed with natural snow. From leaching experiments performed by Tranter et al. (1992), an elution sequence of $\mathrm{SO}_{4}^{2-}>$ $\mathrm{Mg}^{2+}>\mathrm{Na}^{+} \sim \mathrm{NO}_{3}^{-}>\mathrm{Cl}^{-}$was derived. Other studies, however, led to contradicting results. Brimblecombe et al. (1985), for instance, observed in a field study an elution order of $\mathrm{SO}_{4}^{2-}>$ $\mathrm{NO}_{3}^{-}>\mathrm{NH}_{4}^{+}>\mathrm{K}^{+}>\mathrm{Ca}^{2+}>\mathrm{Mg}^{2+}>\mathrm{Na}^{+}$ $>\mathrm{Cl}^{-}$. The elution sequences partly varied depending on the composition of the investigated natural snow pack or on the experimental conditions in the laboratory (Tsiouris et al., 1985). 


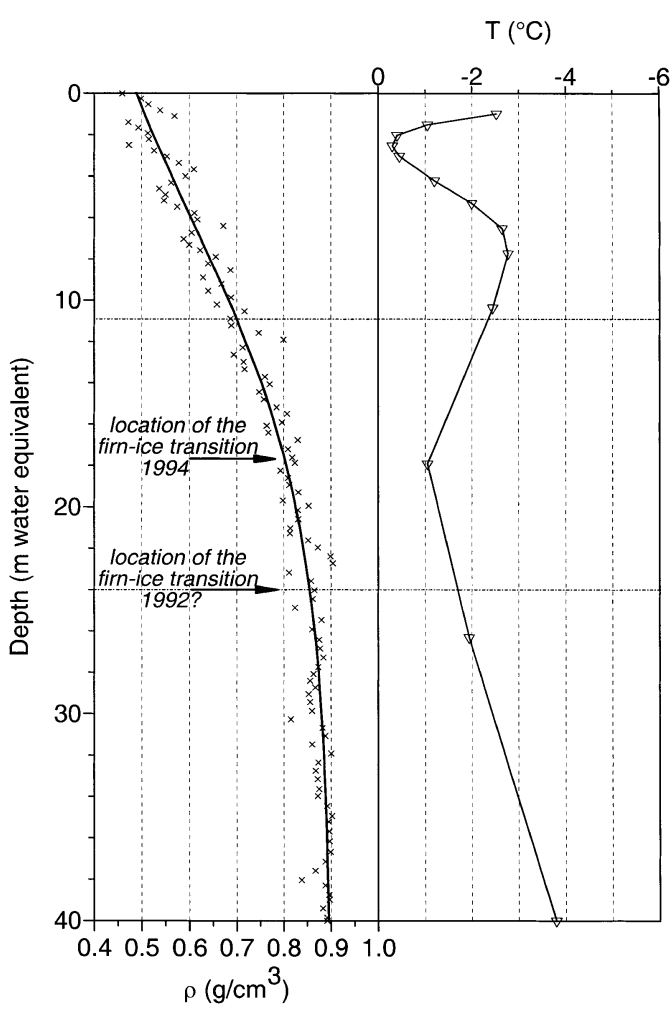

Fig. 5. Profile of the borehole temperatures (triangles; right, data from Suter, 1995) and the firn/ice densities (stars, left) at the upper $40 \mathrm{~m}$ w.eq. The range between 11 and $24 \mathrm{~m}$ w.eq. discussed in this work together with the firn-ice transition at the drilling date (1994) and the assumed firn-ice transition from 1992 are indicated.

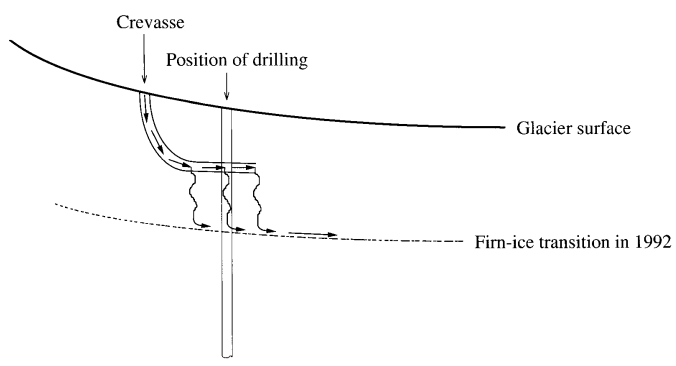

Fig. 6. Scheme of the assumed meltwater flow at the drilling site. The input along a crevasse system in the glacier, the percolation through underlying firn layers and the draining along the firn-ice transition in 1992 are indicated.

\subsection{Possible reasons for the different elution of chemical species}

3 hypotheses will be discussed to explain our observed elution order:

(I) The snow acts as a chromatographic column, retarding certain ions with respect to others.

(II) The position of a species within the elution sequence is dependent on its initial position in the original snow crystal and therefore on precipitation formation and scavenging processes in the atmosphere.

(III) The fractionation processes of chemical species taking place after deposition during the metamorphism from single snow crystal to rounded grains is crucial for the elution order.

(I) The question 'Does snow have ion chromatographic properties?' was investigated by Hewitt et al. (1989). By rinsing a solution of different ions $\left(\mathrm{Cl}^{-}, \mathrm{NO}_{3}^{-}, \mathrm{SO}_{4}^{2-}\right)$ through a column of frozen distilled water drops all three ions eluted with the same retention time. From the simultaneous elution they concluded that snow does not have ion chromatographic properties.

(II) Tsiouris et al. (1985) observed a consistently slower elution of the ions $\mathrm{Cl}^{-}$and $\mathrm{Na}^{+}$ compared to other ions in field studies and laboratory experiments. They argued that sea salt is an important condensation nuclei in the atmosphere, hence, being in the center of a snow crystal. In this case, leaching of $\mathrm{Cl}^{-}$and $\mathrm{Na}^{+}$should be less preferential with respect to those species being attached to the surface of a snow crystal.

The position of a species in a snow crystal is dependent on snow formation and scavenging processes in the atmosphere. Aerosol particles acting as ice nuclei as assumed for soil mineral particles (Szyrmer and Zawadzki, 1997) are usually located in the center of the snow crystal. On the other hand, accretion of supercooled cloud droplets (riming) and the direct impaction of aerosol particles on snow crystals lead to high concentrations of those species at or near the edges of the crystal (Pruppacher and Klett, 1997; Mosimann et al., 1994). An estimate of the relative importance of these processes is very difficult, since they are influenced by a variety of parameters, such as snow crystal size and type, aerosol particle size as well as cloud droplet size. 


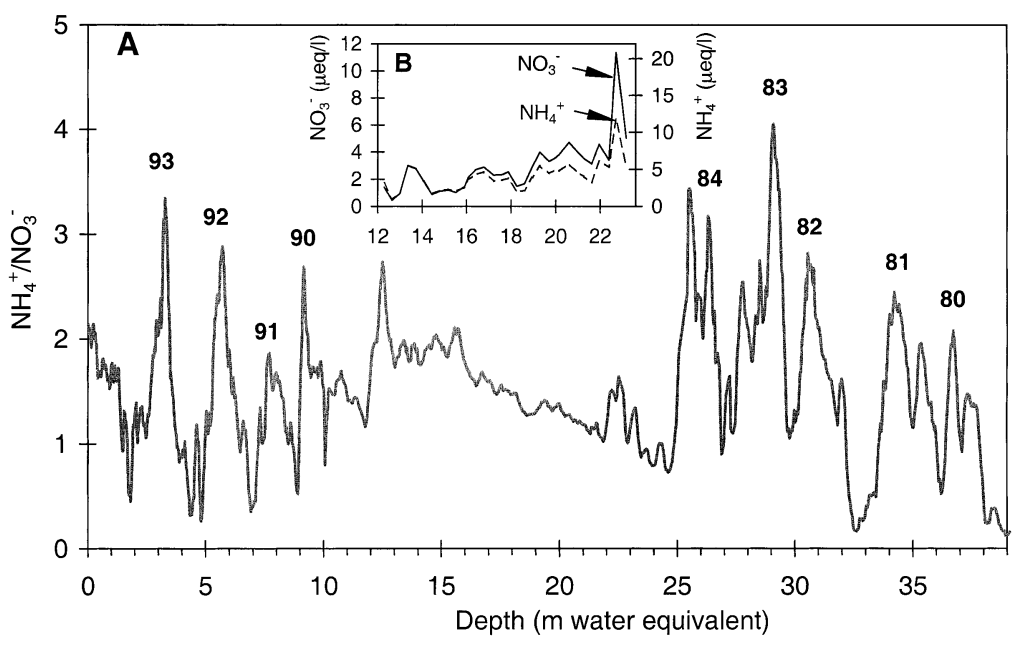

Fig. 7. Record of the $\mathrm{NH}_{4}^{+} / \mathrm{NO}_{3}^{-}$concentration ratio in the upper $39 \mathrm{~m}$ w.eq. (A) together with the concentration records of $\mathrm{NH}_{4}^{+}$(B) dashed line) and $\mathrm{NO}_{3}^{-}$(C) solid line) between 12 and $24 \mathrm{~m}$ w.eq. Dating of the annual layers not affected by the meltwater is additionally included.

Therefore, the location of $\mathrm{NaCl}$ aerosol particles in snow crystals, for instance, varies with the sampling site and the parameters mentioned above. However, a fractionation between $\mathrm{Na}^{+}$and $\mathrm{Cl}^{-}$in the ice crystal is not expected. The aerosol particle is possibly placed as an ice nuclei in the center of the crystal or at the edges after riming processes, for instance. Fig. 8 shows the $\mathrm{Cl}^{-} / \mathrm{Na}^{+}$ ratio of the upper $38 \mathrm{~m}$ w.eq. of the Grenzgletscher ice core. This ratio fluctuates around the sea salt value of 1.16 (Keene et al., 1986) with the exception of the range influenced by meltwater. In this depth range a strongly increased $\mathrm{Cl}^{-} / \mathrm{Na}^{+}$ratio with values up to 20 was detected, indicating a separation of $\mathrm{Na}^{+}$and $\mathrm{Cl}^{-}$from the original sea salt aerosol particle after the deposition.

Therefore we assume that the different elution of the chemical species from the melting snow can not primarily be related to scavenging processes and to the atmospheric history of the initial deposited snow crystals.

(III) After the deposition of individual snowflakes their original form is lost by snow meta-

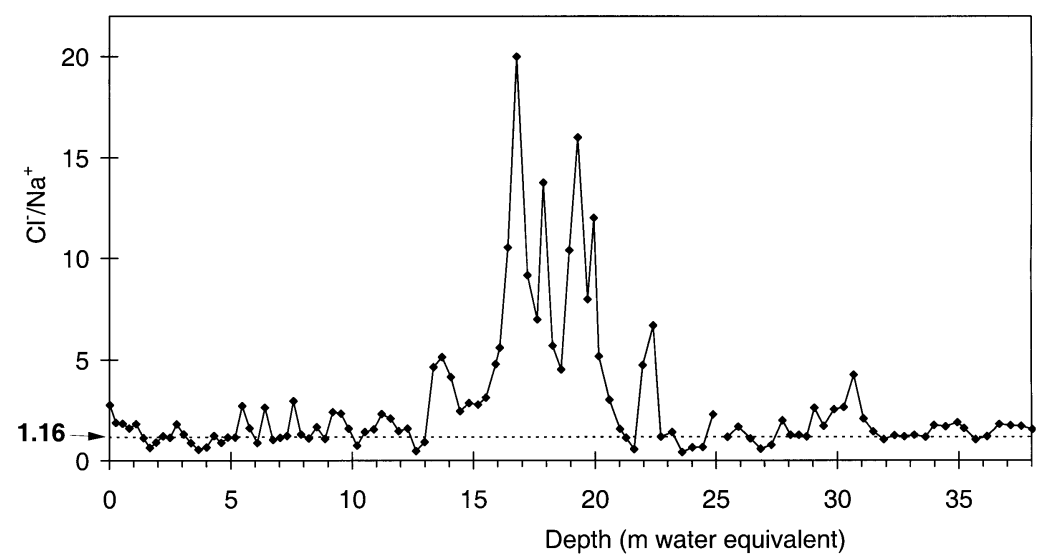

Fig. 8. $\mathrm{Cl}^{-} / \mathrm{Na}^{+}$molar concentration ratio along the ice core (solid line) together with the sea salt ratio of 1.16 (dashed line). 
morphism with aging of the snowpack. Single snow crystals or snow flakes are transformed into rounded snow grains. During the following sintering process the larger grains grow at the expense of smaller ones (Davis, 1991). This grain growth is a process of continuous sublimation-evaporation from warmer and/or more curved surfaces and condensation on colder and/or less curved surfaces. The process is dominated by temperature gradients (Colbeck, 1987).

Snow metamorphism must also affect chemical impurities in the ice and we attribute the observed elution behaviour to different locations in the snow grain occupied by certain species. We assume that two properties of the investigated species are responsible for this fractionation: (i) their capability to form volatile compounds and (ii) their solubility in ice. During the process of sublimation, less volatile solutes are left on residual grain surfaces. Thus, the species $\mathrm{SO}_{4}^{2-}, \mathrm{Ca}^{2+}, \mathrm{Mg}^{2+}$, $\mathrm{K}^{+}$, and $\mathrm{Na}^{+}$might be enriched at these residual surfaces, whereas the species $\mathrm{F}^{-}, \mathrm{Cl}^{-}, \mathrm{NH}_{4}^{+}$, and $\mathrm{NO}_{3}^{-}$may partly escape as volatile compounds $\mathrm{HF}, \mathrm{HCl}, \mathrm{HNO}_{3}$, and $\mathrm{NH}_{4} \mathrm{NO}_{3}$ and condense on new surfaces. Chemical components, initially located at grain surfaces, can partially enter the ice lattice and be incorporated dependent on their solubility in ice. Generally, impurities can be incorporated substitutionally in ice or occupy interstitial sites. The position of a dopant in ice is dependent on its thermodynamically preferred location. In order to be incorporated substitutionally into the grain interior a species must be of a certain size and type to fit into the ice lattice (Wolff, 1996). High solubilities in the ice were reported for $\mathrm{F}^{-}$and $\mathrm{NH}_{4}^{+}$. Both can enter the ice lattice in concentrations up to $10^{-2} \mathrm{~mol}^{-1}$ (Hobbs, 1974). $\mathrm{F}^{-}$(or HF) and $\mathrm{NH}_{4}^{+}$(or $\mathrm{NH}_{3}$ ) can replace $\mathrm{H}_{2} \mathrm{O}$ molecules in the ice structure, since the atomic radii of $\mathrm{F}$ and $\mathrm{N}$ are comparable to that of the O atom (Hobbs, 1974; Pruppacher and Klett, 1997). The substitution creates ionisation and Bjerrum defects in the ice lattice. $\mathrm{F}^{-}$ should produce a deficiency of two protons ( $\mathrm{L}$ defects) and $\mathrm{NH}_{4}^{+}$an excess of two protons (D defects). However, it is not yet clear in which form the species are present in the ice, as ions $\left(\mathrm{F}^{-}\right.$, $\mathrm{NH}_{4}^{+}$) or molecules ( $\mathrm{HF}, \mathrm{NH}_{3}$ ).

It was proposed that the other halides $\left(\mathrm{Cl}^{-}\right.$, $\mathrm{Br}^{-}, \mathrm{I}^{-}$) may be incorporated substitutionally into the lattice as well (e.g., Gross et al., 1978; Riley et al., 1978, Hobbs, 1974). By analyzing ice growing from alkali-halide solutions, they observed that the concentrations of the halide-ions in the ice were typically orders of magnitude higher than the alkali-ion concentrations. While the alkaliions were preferentially excluded from the lattice, the halides may have replaced $\mathrm{H}_{2} \mathrm{O}$ molecules in the lattice. $\mathrm{Cl}^{-}$was found to enter the lattice up to concentrations of about $10^{-5} \mathrm{~mol} \mathrm{l}^{-1}$ (Hobbs, 1974). Thibert and Dominé (1997) report a maximum solubility of $\mathrm{HCl}$ in ice of about $9 \cdot 10^{-5} \mathrm{~mol} \mathrm{l}^{-1}\left(T=-4^{\circ} \mathrm{C}\right)$. From the calculations they assume that $\mathrm{Cl}^{-}$is interstitial, but not substitutional incorporated in the ice lattice. In conclusion, this subject is still discussed controversially.

From investigations of the electrical behaviour of $\mathrm{NO}_{3}^{-}$and $\mathrm{F}^{-}$doped ice (Levi and Arias, 1964) we deduce that $\mathrm{NO}_{3}^{-}$may be incorporated in larger concentrations into the ice lattice too. Dominé and Thibert (1996) and Thibert and Dominé (1998) reported that $\mathrm{HNO}_{3}$ is less soluble in ice than $\mathrm{HCl}$. Maximum solubilities of about $4 \cdot 10^{-6} \mathrm{moll}^{-1}$ were calculated for $\mathrm{HNO}_{3}(T=$ $\left.-4^{\circ} \mathrm{C}\right)$.

From the scarcely disturbed records of the ions $\mathrm{Cl}^{-}, \mathrm{F}^{-}, \mathrm{NH}_{4}^{+}$, and $\mathrm{NO}_{3}^{-}$we assume that maximum concentrations of these species normally observed in the Alpine snow at the site are in the order of magnitude of their solubility in ice or even less. In fact, maximum concentrations of $\mathrm{Cl}^{-}, \mathrm{F}^{-}$, and $\mathrm{NH}_{4}^{+}$in the percolation range (about $1.5 \cdot 10^{-6} \mathrm{~mol}^{-1}, 0.1 \cdot 10^{-6} \mathrm{~mol}^{-1}$ and $5 \cdot 10^{-6} \mathrm{~mol}^{-1}$, respectively) are below the solubility limits reported in the literature (see above). Hence, these species are probably incorporated mainly into the ice lattice, which explains the immobility with respect to the percolating meltwater. The maximum remaining concentration of $\mathrm{NO}_{3}^{-}$(about $5 \cdot 10^{-6} \mathrm{~mol} \mathrm{l}^{-1}$ ), however, is comparable with the maximum solubility of $\mathrm{HNO}_{3}$ in ice proposed by Thibert and Dominé (1998) (see above). This indicates that in agreement with the established elution sequence, $\mathrm{NO}_{3}^{-}$was much less conservative than $\mathrm{Cl}^{-}, \mathrm{F}^{-}$and $\mathrm{NH}_{4}^{+}$, since the part of $\mathrm{NO}_{3}^{-}$above the solubility limit was removed by percolation. Nevertheless, the agreement between the remaining $\mathrm{NO}_{3}^{-}$concentration in the firn and the maximum solubility of $\mathrm{HNO}_{3}$ in ice is astonishing, since $\mathrm{NO}_{3}^{-}$is not present as $\mathrm{HNO}_{3}$ but most probably as $\mathrm{NH}_{4} \mathrm{NO}_{3}$ 
at the given pH (Table 1). Gross and Svec (1997) showed that $\mathrm{NH}_{4}^{+}$enhances the solubility of various anions in ice. Our results could indicate that $\mathrm{NO}_{3}^{-}$was present as $\mathrm{HNO}_{3}$ in the ice lattice, although it was originally deposited as $\mathrm{NH}_{4} \mathrm{NO}_{3}$.

To our knowledge, data on the solubility of the species $\mathrm{K}^{+}, \mathrm{Na}^{+}, \mathrm{Mg}^{2+}, \mathrm{Ca}^{2+}$, and $\mathrm{SO}_{4}^{2-}$ in ice are lacking. Cations $\mathrm{Ca}^{2+}, \mathrm{Mg}^{2+}, \mathrm{K}^{+}$, and $\mathrm{Na}^{+}$ were estimated to enter the ice lattice only in very small concentrations, orders of magnitude lower than that of the anions $\mathrm{F}^{-}$and $\mathrm{Cl}^{-}$(Gross et al., 1978). Therefore these species are probably located mainly at the grain boundaries and can move to the firn grain surface by diffusion processes. From the grain surfaces they are easily washed out by rinsing melt water. The fact that $\mathrm{SO}_{4}^{2-}$ is not located in the grain interior, but at the grain boundary was verified for Antarctic ice (Mulvaney et al., 1988 and Fukazawa et al., 1998). They estimated that $40-100 \%$ of the sulphate is present as a concentrated sulphuric acid solution at the triple junctions (junctions where three grains are in contact), whereas sulphate could not be detected in the bulk of the ice (detection limit $5 \mathrm{mM}$ ).

Assuming that $\mathrm{K}^{+}, \mathrm{Na}^{+}, \mathrm{Mg}^{2+}, \mathrm{Ca}^{2+}$, and $\mathrm{SO}_{4}^{2-}$ were incorporated into the ice lattice up to their limit of solubility we deduced from the remaining concentrations in the strongly depleted part between about 14 and $21 \mathrm{~m}$ w.eq. the maximum values for the solubility of these species in ice under existing conditions $\left(\left[\mathrm{K}^{+}\right]\right.$ $<0.03 \cdot 10^{-6} \mathrm{~mol} \mathrm{l}^{-1},\left[\mathrm{Na}^{+}\right]<0.03 \cdot 10^{-6} \mathrm{~mol}^{-1}$, $\left[\mathrm{Mg}^{2+}\right]<0.02 \cdot 10^{-6} \mathrm{moll}^{-1},\left[\mathrm{Ca}^{2+}\right]<0.08$. $10^{-6} \mathrm{~mol}^{-1}$, and $\left[\mathrm{SO}_{4}^{2-}\right]=0.12 \cdot 10^{-6} \mathrm{~mol}^{-1}$ ). Except for $\mathrm{SO}_{4}^{2-}$ all values given represent the respective detection limits of the analytical method.

The main reason to explain our observed elution sequence is therefore the different solubility of the species in ice. Species with concentrations below the solubility limit were preferably incorporated into the ice lattice and were relatively immobile with respect to the percolating meltwater. A higher mobility is observed for those species with concentrations above the solubility limit causing their segregation at the grain surfaces. For this reason, snow covers with higher concentrations of the impurities may show a different elution sequence compared to those with lower impurity levels, as reported by Brimblecombe et al. (1988), for instance. The same study indicates different solu- bilities of an ionic species in ice with varying chemical composition, which was already mentioned (see above). Furthermore, a dependence of the redistribution processes of the chemical species at the grain scale on time was observed (Brimblecombe et al., 1987; Cragin et al., 1996). Preferential elution was found to be more pronounced in aged samples compared to fresh snow due to the advancing snow metamorphism. Thus, also the initial snow concentrations, the chemical composition and the time available for the redistribution processes might affect the elution sequence, explaining partially the different findings reported in the literature (Subsection 3.2).

\section{Summary and conclusions}

A strong post-depositional process, the leaching of solutes from firn by meltwater, was detected in a firn and ice core from Grenzgletscher. Because of the preserved $\delta^{18} \mathrm{O}$ profile and the distinct stratigraphy we deduce that the firn layer was only partially melted at the grain surfaces. Chemical species were leached with different efficiencies. Scavenging processes in the atmosphere during precipitation formation and ion chromatographic processes in the firn layer could not explain the observed elution sequence. Only rearrangement processes during snow metamorphism combined with different solubilities of species in ice determine their position at the grain scale. Ions, favourably incorporated in the ice lattice resulting in high solubility were found to be relatively immobile with respect to the percolating meltwater and are therefore placed at the end of the established elution sequence. Exclusion of ions above solubility limit from the ice lattice into boundary regions during grain growth led to a fast removal of those species by percolating meltwater. However, future studies are needed for a better understanding of these processes, focusing on the quantification of the solubility of chemical species in ice under different bulk compositions in order to explain observed elution sequences in more detail.

\section{Acknowledgements}

We thank T. Blunier, T. Döring, A. Döscher, V. Lavanchy, H. Rufli, and J. Schwander for their 
engagement in the field. The support of M. Saurer, R. Siegwolf, K. Bleidissl, and E. Rössler for the $\delta^{18} \mathrm{O}$ analyses is gratefully acknowledged. We thank S. Nyeki and C. N. Hewitt for carefully reading the manuscript. The generous support of the Aargauische Zentralmolkerei, Suhr, storing the ice cores at stable deep freeze conditions is highly acknowledged. This work was partly supported by the Swiss National Science Foundation (Project NFP-31). The comments of the two anonymous reviewers improved the clarity of this manuscript, and we are grateful for their suggestions.

\section{REFERENCES}

Bales, R. C., Davies, R. E. and Stanley, D. A. 1989. Ion elution through shallow homogeneous snow. Water Resources Research 25, 1869-1877.

Brimblecombe, P., Tranter, M., Abrahams, P. W., Blackwood, I., Davies, T. D. and Vincent, C. E. 1985. Relocation and preferential elution of acidic solute through the snowpack of a small, remote, high-altitude Scottish catchment. Annals of Glaciology 7, 141-147.

Brimblecombe, P., Clegg, S. L., Davies, T. D., Shooter, D. and Tranter, M. 1987. Observations of the preferential loss of major ions from melting snow and laboratory ice. Water Research 21, 1279-1286.

Brimblecombe, P., Clegg, S. L., Davies, T. D., Shooter, D. and Tranter, M. 1988. The loss of halide and sulphate ions from melting ice. Water Res. 22, 693-700.

BUWAL. 1999. NABEL-Luftbelastung 1998. Messresultate des Nationalen Beobachtungsnetzes für Luftfremdstoffe, Schriftenreihe Umwelt Nr. 311, Bundesamt für Umwelt, Wald und Landschaft (BUWAL), Bern, Switzerland, 194 pp.

Colbeck, S. C. 1987. Snow metamorphism and classification. In: Seasonal snowcovers: physics, chemistry and hydrology (eds. H. G. Jones and W. J. Orville-Thomas) D. Reidel, Dortrecht, pp. 1-35.

Cragin, J. H., Hewitt, A. D. and Colbeck, S. C. 1996. Grain-scale mechanisms influencing the elution of ions from snow. Atmospheric Environment 30, 119-127.

Dansgaard, W. 1964. Stable isotopes in precipitation. Tellus 16, 436-468.

Davis, R. E. 1991. Links between snowpack physics and snowpack chemistry. In: Seasonal snowpacks: processes of compositional change (eds. T. D. Davies, M. Tranter and H. G. Jones). Springer Verlag, Berlin, etc. pp. 115-138. (NATO ASI Series G: Ecological Sciences 28.)

de Angelis, M. and Legrand, M. 1994. Origins and variations of fluoride in Greenland precipitation Journal of Geophysical Research 99 (D1), 1157-1172.

Delmas, R. J. 1993. A natural artefact in Greenland icecore $\mathrm{CO}_{2}$ measurements. Tellus 45B, 391-396.

Dominé, F. and Thibert, E. 1996. Mechanism of incorporation of trace gases in ice grown from the gas phase. Geophysical Research Letters 23, 3627-3630.

Eichler, A., Schwikowski, M., Gäggeler, H. W., Furrer, V., Synal, H.-A., Beer, J., Saurer, M. and Funk, M. 2000 Glaciochemical dating of an ice core from the upper
Grenzgletscher (4200 m a.s.1.). Journal of Glaciology 46, 507-515.

Fukazawa, H., Sugiyama, K., Mae, S., Narita, H. and Hondoh, T. 1998. Acid ions at triple junction of Antarctic ice observed by Raman scattering. Geophysical Research Letters 25, 2845-2848.

Gäggeler, H. W., Stauffer, B., Döscher, A. and Blunier, T. 1997. Klimageschichte im Alpenraum aus Analysen von Eisbohrkernen. Vdf Hochschulverlag AG, Zürich, $61 \mathrm{pp}$.

Goto-Azuma, K., Nakawo, M., Jiankang, H., Watanabe, O. and Azuma, N. 1994. Melt-induced relocation of ions in glaciers and in a seasonal snowpack. IAHS Publication No. 223, pp. 287-298.

Gross, G. W., Hayslip, I. C. and Hoy, R. N. 1978. Electrical conductivity and relaxation in ice crystals with known impurity content. Journal of Glaciology 21, $143-159$.

Gross, G. W. and Svec, R. K. 1997. Effect of ammonium on anion uptake and dielectric relaxation in laboratory-grown ice columns. Journal of Physical Chemistry B 101, 6282-6284.

Hewitt, A. D., Cragin, J. H. and Colbeck, S. C. 1989. Does snow have ion chromatographic properties? In: Proceedings of the 46th Annual Eastern Snow Conference, 8-9 June, Quebec City, Quebec, pp. 165-171.

Hewitt, A. D., Cragin, J. H. and Colbeck, S. C. 1991. Effects of crystal metamorphosis on the elution of chemical species from snow. In: Proceedings of the 48th Annual Eastern Snow Conference, Guelph, Ontario, 2-10 June.

Hobbs, P. V. 1974. Ice physics. Oxford, Clarendon press, $837 \mathrm{pp}$.

Johannessen, M. and Henriksen, A. 1978. Chemistry of snow meltwater: Changes in concentration during melting. Water Resources Research 14, 615-619.

Johnsen, S. J. 1977. Stable isotope homogenization of polar firn and ice. In: Proceedings of the Grenoble Symposium, Aug./Sept. 1975, IAHS-AISH Publication No. 118, pp. 210-219.

Keene, W. C., Pszenny, A. A. P., Galloway, J. N. and Hawley, M. E. 1986. Sea-salt corrections and interpretation of constituent ratios in marine precipitation. Journal of Geophysical Research 91 (D6), 6647-6658. Kreutz, K. J., Mayewski, P. A., Whitlow, S. I. and Twickler, M. S. 1998. Limited migration of soluble 
ionic species in a Siple Dome, Antarctica, ice core Annals of Glaciology 27, 371-377.

Levi, L. and Arias, D. 1964. Conductivité en courant continu de la glace dopée avec différents hydracides. J. Chim. Phys. 61, 668-671.

Lugauer, M., Baltensperger, U., Furger, M., Gäggeler, H. W., Jost, D. T., Schwikowski, M. and Wanner, H. 1998. Aerosol transport to the high Alpine sites Jungfraujoch (3454 $\mathrm{m}$ asl) and Colle Gnifetti (4452 $\mathrm{m}$ asl). Tellus 50B, 76-92.

Maupetit, F., Wagenbach, D., Weddeling, P. and Delmas, R. J. 1995. Seasonal fluxes of major ions to a high altitude cold alpine glacier. Atmospheric Environment 29, 1-9.

Mosimann, L., Weingartner, E. and Waldvogel, A. 1994 An analysis of accreted drop sizes and mass on rimed snow crystals. Journal of the Atmospheric Sciences $\mathbf{5 1}$ $1548-1558$.

Mulvaney, R., Wolff, E. W. and Oates, K. 1988. Sulphuric acid at grain boundaries in Antarctic ice. Nature 331, 247-249.

Pruppacher, H. R. and Klett, J. D. 1997. Microphysics of clouds and precipitation. Kluwer Academic Publishers, Netherlands, 954 pp.

Riley, N. W., Noll, G. and Glenn, J. W. 1978. The creep of NaCl-doped ice monocrystals. Journal of Glaciology 21, 501-507.

Schotterer, U., Fröhlich, K., Gäggeler, H. W., Sandjordj, S. and Stichler, W. 1997. Isotope records from Mongolian and Alpine ice cores as climate indicators. Clim. Change 36, 519-530.

Schwander, J. 1996. Gas diffusion in firn. In: Chemical exchange between the atmosphere and polar snow (eds E. W. Wolff and R. C. Bales). Springer Verlag, Berlin, etc., pp. 527-540. (NATO ASI Series I: Global environmental change 43.)

Schwikowski, M., Brütsch, S., Gäggeler, H. W. and
Schotterer, U. 1999. A high resolution air chemistry record from an Alpine ice core: Fiescherhorn glacier, Swiss Alps. Journal of Geophysical Research 104 (D11), 13,709-13,720.

Sigg, A. and Neftel, A. 1991. Evidence for a 50\% increase in $\mathrm{H}_{2} \mathrm{O}_{2}$ over the past 200 years from a Greenland ice core. Nature 351, 557-559.

Suter, S. 1995. Die Verbreitung kalter Firn- und Eisregionen im Alpengebiet. Diploma Thesis, ETH Zürich, Switzerland.

Szyrmer, W. and Zawadzki, I. 1997. Biogenic and anthropogenic sources of ice-forming nuclei: a review. Bulletin of the American Meteorological Society 78, 209-228.

Thibert, E. and Dominé, F. 1997. Thermodynamics and kinetics of the solid solution of $\mathrm{HCl}$ in ice. Journal of Physical Chemistry B 101, 3554-3565.

Thibert, E. and Dominé, F. 1998. Thermodynamics and kinetics of the solid solution of $\mathrm{HNO}_{3}$ in ice. Journal of Physical Chemistry B 102, 4432-4439.

Tranter, M., Tsiouris, S., Davies, T. D. and Jones, H. G 1992. A laboratory investigation of the leaching of solute from snowpack by rainfall. Hydrol. Process. 6, 169-178.

Tsiouris, T., Vincent, C. E., Davies, T. D. and Brimblecombe, P. 1985. The elution of ions through field and laboratory snowpacks. Annals of Glaciology 7, 196-201.

Wagnon, P., Delmas, R. J. and Legrand, M. 1999. Loss of volatile acid species from upper firn layers at Vostok, Antarctica. Journal of Geophysical Research 104 (D3), 3423-3431.

Wolff, E. W. 1996. Location, movement and reactions of impurities in solid ice. In: Chemical exchange between the atmosphere and polar snow (eds. E. W. Wolff and R. C. Bales). Springer Verlag, Berlin, etc., pp. 541-560. (NATO ASI Series I: Global environmental change 43.) 